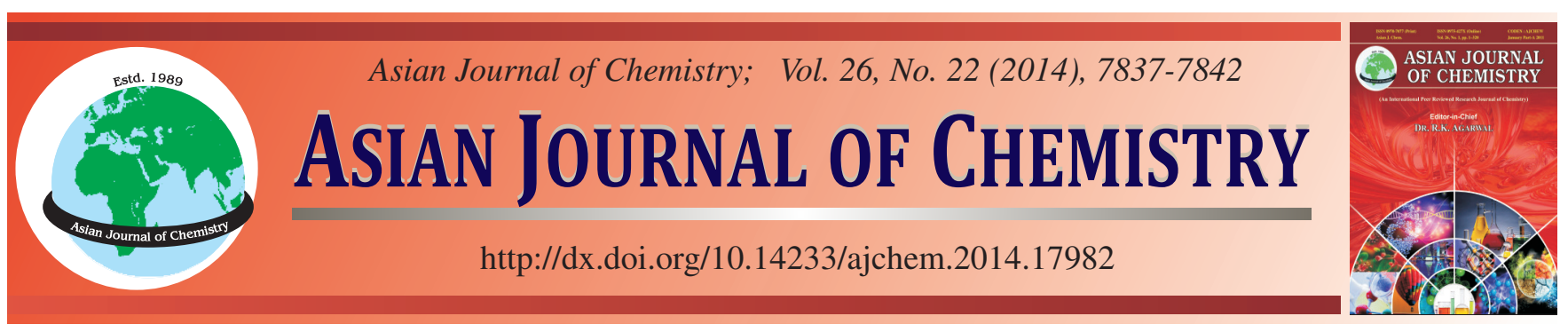

\title{
Molluscicidal Activity of Some Cyanide Derivatives
}

\author{
Ahmed S. Abdel-Atr ${ }^{1, *}$ and Ahmed Abdel-Megeed ${ }^{2,3}$
}

\begin{abstract}
${ }^{1}$ Department of Pesticide Chemistry and Technology, Faculty of Agriculture, 21545-El-Shatby, Alexandria University, Alexandria, Egypt ${ }^{2}$ Department of Plant Protection, Faculty of Agriculture, (Saba Basha), Alexandria University, Alexandria, Egypt

${ }^{3}$ Botany and Microbiology Department, College of Science, King Saud University, P.O. Box 2455, Riyadh 11451, Saudi Arabia
\end{abstract}

*Corresponding author: E-mail: sabry2000@yahoo.com; aamahmoud@ksu.edu.sa

\begin{abstract}
Eleven cyanide derivatives were used to stand on molluscicidal effects against Theba pisana. Acetone cyanohydrin and acetophenone cyanohydrin were prepared. Acetonitrile was too weak to cause $50 \%$ mortality at the highest concentration for 10 days. Ethylcyanoacetic acid ester was more effective than acetonitrile. $100 \%$ mortality of the population at $0.1 \%$ after 4 and 7 days, respectively was achieved with $<2$ days $\mathrm{LT}_{50}$ values at all concentrations except at $0.5 \%$, the second exhibited 4.2 day $\mathrm{LT}_{50}$ value. Lethal effects of the inorganic cyanides were differed according to their structure, concentration and exposure time. Although cuprous thiocyanate (CuSCN) showed weak molluscicidal activity with mortality $(23.8 \%)$, it appeared more effective than potassium ferrocyanide and potassium ferricyanide. Potassium thiocyanate showed low toxicity against the treated snail. Mercuric cyanide $\left[\mathrm{Hg}(\mathrm{CN})_{2}\right]$ exceeded the other inorganic derivatives except potassium cyanide and sodium cyanide that were the most active compounds with non significance between each other.
\end{abstract}

Keywords: Cyanide, Ethylcyanoacetic acid ester, Acetonecyanohydrin, Acetophenone cyanohydrin, Theba pisana, Molluscicidal activity.

\section{INTRODUCTION}

White garden snail, Theba pisana (Muller) is a serious agricultural pest fed on leaves, flowers and soft apical parts of plants causing economic problems to fruits, vegetables, ornamentals and field crops $^{1,2}$. Till now, synthetic molluscicides and insecticides are still being applied for controlling snails ${ }^{3}$. Intensive studies have been carried out to find safe alternatives as toxicants present in different plant families ${ }^{4}$. Prunus armeniaca, a cyanogenic plant contains amygdalin and other cyanogenic glycosides, which have antimicrobial activities against Helicobacter pylori, both Gram-positive and Gramnegative bacteria and fungi ${ }^{5}$. Amygdalin and prunasin are found in more than 2500 different species including many important crop plants ${ }^{6}$. Cyanogenic glycosides protect their contained plants from animals ${ }^{7}$. Their effect is referred to hydrolysis liberating cyanide expressed as hydrocyanic acid ( $\mathrm{HCN})$, which has acute toxicity as it is well known and other corresponding carbonyl components ${ }^{8}$. We previously confirmed the mortal effect of both amygdalin and prunasin in Prunus armeniaca kernels to be quantitatively against the land snail, Theba pisana (Muller) ${ }^{9}$. Cyanide-producing clover plants are typically protected from small herbivores such as slugs, snails, voles and insects, which are a major source of predation. Calcium cyanide is being used to control vector snails in different countries ${ }^{10}$.
Because the molluscicidal activity of cyanogenic glycosides is referred to their hydrolysis and production of hydrogen cyanide we tried in this study to evaluate the lethal effect of some organic and inorganic cyanide derivatives against the land snail, Theba pisana (Muller), to reach the most effective structure killing this pest with pointing to their environmental impacts.

\section{EXPERIMENTAL}

Tested compounds: Eleven cyanide derivatives were used in this study to stand on their molluscicidal effects. These compounds are tabulated in Table- 1 .

Four liquid organic cyanide derivatives were used in this study. They are acetonitrile and ethyl cyano-acetic acid ester (VEB LABOR CHEMIE, APOLADA, Germany) as well as both acetone cyanohydrin and acetophenone cyanohydrin that were prepared.

Seven metalocyanide derivatives (solid, inorganic) were also used in this study. They are cuprous thiocyanate (Oxford Laboratory reagent CAN number111-67-7), mercuric cyanide (PROLABO LOT 82188), potassium cyanide, potassium ferrocyanide (Chemical Production and Importing CO), potassium ferricyanide (Loba Chemie Put Ltd.), potassium thiocyanate (Merk) and sodium cyanide (Universal Fine 
TABLE - 1

TESTED CYANIDE DERIVATIVES

\begin{tabular}{|c|c|c|c|}
\hline Chemical name & Chemical structure & m.w. & $\mathrm{CN}(\%)$ \\
\hline Acetonitrile & $\mathrm{CH}_{3} \mathrm{CN}$ & 41 & 63.4 \\
\hline Acetone-cyanohydrin & $\begin{array}{l}\mathrm{H}_{3} \mathrm{C}>\mathrm{C}^{-}=\mathrm{OH} \\
\mathrm{H}_{3} \mathrm{C}^{\prime}-\mathrm{CN}\end{array}$ & 85 & 30.6 \\
\hline $\begin{array}{l}\text { Acetophenone- } \\
\text { cyanohydrin }\end{array}$ & & 147 & 17.7 \\
\hline $\begin{array}{c}\text { Ethylcyanoacetic acid } \\
\text { ester }\end{array}$ & $\stackrel{\stackrel{\mathrm{O}}{\mathrm{C}} \mathrm{C}_{2} \mathrm{H}_{5} \mathrm{O}-\stackrel{\mathrm{C}}{\mathrm{C}}-\mathrm{CH}_{2} \mathrm{CN}}{\mathrm{Cl}}$ & 113 & 23.0 \\
\hline Cuprous thiocyanate & $\mathrm{CuSCN}$ & 121.62 & 21.4 \\
\hline Mercuric cyanide & $\mathrm{Hg}(\mathrm{CN})_{2}$ & 252.63 & 20.6 \\
\hline Potassium cyanide & $\mathrm{KCN}$ & 65.1 & 39.9 \\
\hline Potassium ferrocyanide & $\mathrm{K}_{4} \mathrm{Fe}(\mathrm{CN})_{6}$ & 368.41 & 42.4 \\
\hline Potassium ferricyanide & $\mathrm{K}_{3} \mathrm{Fe}(\mathrm{CN})_{6}$ & 329.62 & 47.3 \\
\hline Potassium thiocyanate & $\mathrm{KSCN}$ & 97.18 & 26.8 \\
\hline Sodium cyanide & $\mathrm{NaCN}$ & 49.01 & 53.1 \\
\hline
\end{tabular}

Chemicals Pvt. Ltd., India). Except both acetone cyanohydrin and acetophenone cyanohydrin that were prepared according to Vogel \& Abdel-Aty ${ }^{11,12}$, all of the tested derivatives and other used chemicals were purchased from El-Gomhouria Drug Company, Egypt.

Preparation of acetone-cyanohydrin: Acetone cyanohydrin was prepared by swirling a mixture of $100 \mathrm{~mL}$ of $55 \%$ cold aqueous sodium metabisulphite $\left(\mathrm{Na}_{2} \mathrm{~S}_{2} \mathrm{O}_{5}\right)$ and slowly added $29 \mathrm{~g}$ of acetone $(36.25 \mathrm{~mL}, 0.5 \mathrm{~mol})$ in $1 \mathrm{~L}$ flask with subsequent added $100 \mathrm{~mL}$ of $30 \%$ aqueous potassium cyanide. The two fractions were combined and the yield was separated as the upper layer. Another fraction was extracted with chloroform $(75 \mathrm{~mL})$. The yield was dried with anhydrous sodium sulfate to $31.5 \mathrm{~g}(73 \%)$ as a clear yellow liquid (Scheme-I).

Preparation of acetophenone-cyanohydrin: Acetophenone cyanohydrin was prepared by swirling a mixture of $100 \mathrm{~mL}$ of $55 \%$ cold aqueous sodium metabisulphite $\left(\mathrm{Na}_{2} \mathrm{~S}_{2} \mathrm{O}_{5}\right)$ and slowly added $60 \mathrm{~g}$ of acetophenone $(58.3 \mathrm{~mL}, 0.5 \mathrm{~mol})$ in $1 \mathrm{~L}$ flask with subsequent added $100 \mathrm{~mL}$ of $30 \%$ aqueous potassium cyanide. The two fractions were combined and the yield was separated as the upper layer. Another fraction was extracted with chloroform $(75 \mathrm{~mL})$. The yield was dried with anhydrous sodium sulfate to $51.1 \mathrm{~g}(70 \%)$ as a bright yellowish liquid (Scheme-I).

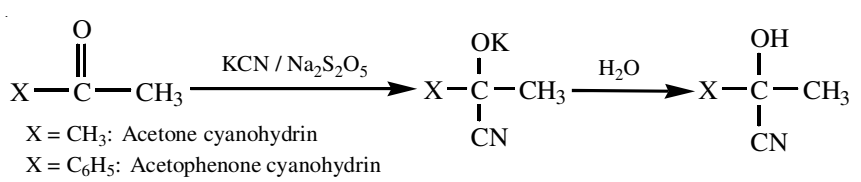

Scheme-I: Synthesis of acetone cyanohydrin and acetophenone cyanohydrin

Identification of the prepared compounds: Both acetone cyanohydrin and acetophenone cyanohydrin were confirmed for their structure using mass spectroscopic measurement in the Central Laboratory, Faculty of Agriculture, Alexandria University, Egypt. Mass spectra were recorded using the mass unit of Thermo GC-MS ISQ single quadruple spectrometer. Column TG-5MS $(30 \mathrm{~m} \times 0.32 \mathrm{~mm} \times 0.25 \mu \mathrm{m})$ was used, sample was injected in acetone $(1.0 \mu \mathrm{L})$ at a concentration of $0.5 \mathrm{mg} / \mathrm{mL})$ in a splitless mode. The applied oven temperature was programmed included an initial step for $1 \mathrm{~min}$ at $30^{\circ} \mathrm{C}$ and increased to $100{ }^{\circ} \mathrm{C}$ within $5 \mathrm{~min}$. Scan was continued up to $8 \mathrm{~min}$ with temperature ramp of $10^{\circ} \mathrm{C} / \mathrm{min}$. using the DIP detector. Ion source temperature was $200^{\circ} \mathrm{C}$ and mass transfere temperature was $250{ }^{\circ} \mathrm{C}$. EI ionization mode at $70 \mathrm{eV}$ with $\mathrm{m} / \mathrm{z}$ range of 50-350 was used.

Tested animal: The white garden snail, Theba pisana (Muller), family Heliecidae was collected from the campus of Faculty of Agriculture, Alexandria University, Alexandria, Egypt and kept for adaptation under laboratory conditions for 2 weeks.

Bioassay test: The used bait was prepared on the wheat bran according to Miller et al. ${ }^{2}$. Water was added at $20 \%$ of the prepared bait. Five grams of the tested bait were introduced in a Petri dish $(9 \mathrm{~cm})$ to ten snails in each replicate. The Petri dish was placed in a plastic pot covered with a piece of fixed cloth. The cloth pieces were daily sprayed with water to keep the moisture. Three replicates were used for each treatment and control was concurrently carried out. The tested compounds were examined at $0.1,0.5,1.0,2.0,5.0$ and $10 \%$ of the used bait and introduced to the tested animal as non-choice food. Number of dead snails was recorded and excluded at different times (2, 4, 7 and 10 days). Mortality percents, lethal concentration that caused $50 \%$ mortality $\left(\mathrm{LC}_{50}\right)$ and lethal time needed to cause $50 \%$ mortality $\left(\mathrm{LT}_{50}\right)$ at each concentration were calculated for each treatment.

Statistical analysis: Mortality percents were calculated and analyzed using the analysis of variance (ANOVA). Both LC50 and LT50 values with $95 \%$ confidence limits were determined using probit analysis ${ }^{13}$.

\section{RESULTS AND DISCUSSION}

Structure confirmation of the prepared compounds: Mass spectra of acetone cyanohydrin and acetophenone cyanohydrin are shown in Figs. 1 and 2, from which it could be deduced that acetone cyanohydrin molecular ion peak appeared at $\mathrm{m} / \mathrm{z}, 147$ with $14.7 \%$ relative abundance. Loss of the methyl group lead to fragment ion at $\mathrm{m} / \mathrm{z} 132$ with $55.2 \%$ relative abundance, while loss of $\mathrm{HCN}$ molecule produced acetophenone molecular ion peak at $m / z 120$ with $75.9 \%$ relative abundance emphasizing our biological data and supporting the fact describes that the toxicity of these compounds is hydrogen cyanide $(\mathrm{HCN})$ releasing dependent phenomena. The acetophenone moiety was re-fragmented to molecular ions at $\mathrm{m} / \mathrm{z}, 105$ and 77 reflecting benzoyl and phenyl ions, respectively due to breaking down of bonds around the carbonyl group.

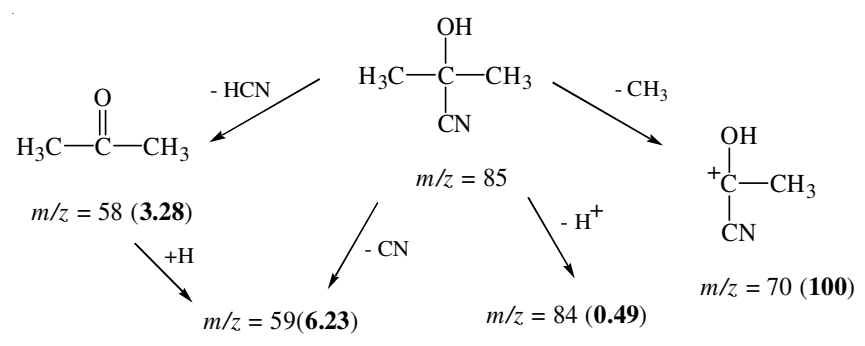

Fig. 1. Fragmentation pathways of acetone cyanohydrin

Regarding the acetone cyanohydrin, the main fragmentation pathways of the parent molecular ion is loss of the hydrogen 


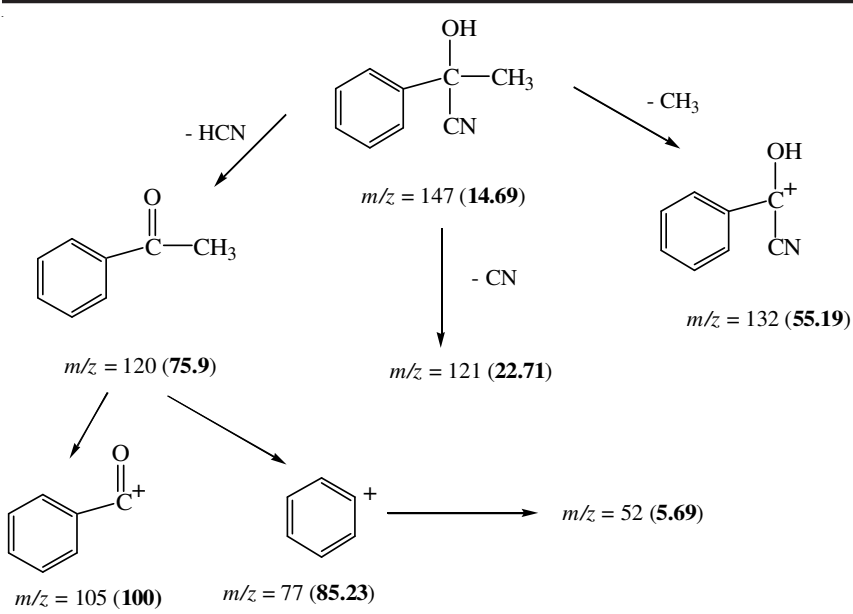

Fig. 2. Fragmentation pathways of acetophenone cyanohydrin

cyanide molecule to produce the acetone molecular ion at $\mathrm{m} / \mathrm{z}$ 58 with $3.28 \%$ relative abundance reflecting the fact of its toxicity is HCN releasing dependent. The acetone molecule was protonated to $\mathrm{m} / z 59$ (6.23\% relative abundance), which may be produced by loss of $\mathrm{CN}^{-}$ion from the molecular ion peak $\left(\mathrm{M}^{+}-\mathrm{CN}\right)$ The base peak at $m / z 70$ is due to loss of methyl group from the parent molecular ion. Molecular ion peak at $\mathrm{m} / \mathrm{z} 84$ may be due to deprotonation of the parent compound as an alcohol. Fragmented ions appeared at $\mathrm{m} / \mathrm{z}, 71$ and 72 with 0.37 and $4.86 \%$ relative abundances are due to $M+1$ and $\mathrm{M}+2$ ions of $\left(\mathrm{M}^{+}-\mathrm{CH}_{3}\right)$ molecular ion. Fragments with their relative abundances of the two compounds are tabulated in Table-2.

TABLE-2

MASS SPECTRA OF THE TWO PREPARED COMPOUNDS

\begin{tabular}{ll}
\hline \multicolumn{1}{c}{ Compound } & \multicolumn{1}{c}{ Relative abundance $(\mathrm{m} / \mathrm{z})$} \\
\hline Acetone & $84(0.49), 71(4.86), 70(100), 69(7.54), 68(4.70)$, \\
cyanohydrin & $59(6.23), 58(3.28), 54(1.84), 52(2.31), 51(1.39)$ \\
\hline \multirow{2}{*}{$\begin{array}{l}\text { Acetophenone } \\
\text { cyanohydrin }\end{array}$} & $\begin{array}{l}(77.90), 14.96), 132(55.19), 121(22.71), 120 \\
(85.23), 52(5.69), 51(47.16)\end{array}$ \\
\hline
\end{tabular}

Molluscicidal activity of the tested compounds: Molluscicidal activity against the treated snail, Thepa pisana was differed according to the tested compound, its concentration and the exposure time. The obtained results are shown in Tables 3 and 4.

Acetonitrile was too weak to cause $50 \%$ mortality even at the highest concentration (10\%) for the longest exposure time (10 days) indicating its low toxicity. Ethylcyanoacetic acid ester was more effective than acetonitrile causing mortality percents ranged from 3.3-26.7, 3.3-36.7, 3.3-66.7 and 6.7$73.3 \%$ at the concentration range of $0.1-10 \%$ with lethal concentration caused $50 \%$ mortality $\left(\mathrm{LC}_{50}\right)$ values equaled $>$ $10,>10,9.1$ and $6.1 \%$ after $2,4,7$ and 10 days exposure, respectively. This effect was enhanced to $100 \%$ mortality of the treated snail population in case of both acetone cyanohydrin and acetophenone cyanohydrin at $0.1 \%$ after 4 days and 7 days exposure, respectively. The two compounds caused $\mathrm{LC}_{50}$ values of $0.43,0.34,0.24$ and $0.18 \%$ in comparison to 0.58 , $0.43,0.29$ and $0.21 \%$ after $2,4,7$ and 10 days exposure, respectively. Regarding the time required achieving $50 \%$ mortality
$\left(\mathrm{LT}_{50}\right)$ was $>10$ days at the used concentration range of acetonitril which indicated the necessity to increase the highest concentration. Ethylcyano acetic acid ester caused $\mathrm{LT}_{50}>10$ days till $5 \%$ concentration, followed by 4.8 days at $10 \%$ concentration.

Both acetone cyanohydrin and acetophenone cyanohydrin caused their effects with $<2$ days $\mathrm{LT}_{50}$ values at all the tested concentrations except the second exhibited 4.2 days $\mathrm{LT}_{50}$ value at $0.5 \%$.

Different activities of the tested organic cyanides are due to their different abilities to liberate the toxic cyanide in $\mathrm{HCN}$ molecule or in cyanide ion $\left(\mathrm{CN}^{-}\right)$as they are the primary toxic agents regardless the origin. In case of acetonitrile, it is difficult to dissociate and produce $\mathrm{HCN}$ because of the electron donating effect of the methyl group. Although its cyanide content is $63.4 \%$ (the highest percent in the tested organic compounds).

Although ethyl cyanoacetic acid ester contains only $23 \%$ cyanide, it appeared more effective than acetonitril due to its easier production of $\mathrm{HCN}$. This effect is referred to the presence of carbonyl group that its effect was reduced due to the presence of $\mathrm{CH}_{2}$ group.

High activity of both cyanohydrin derivatives reflects their easy production of $\mathrm{HCN}$ molecule (the toxic molecule) as their structures dissociate producing the toxic molecule either outside or inside the treated snail through hydroxynitriles lyases. These data go with that exhibited by Poulton ${ }^{14}$ as he showed that hydroxynitriles may decompose spontaneously or enzymatically in the presence of hydroxynitrile lyase to produce hydrogen cyanide and an aldehyde or ketone as the following equation:

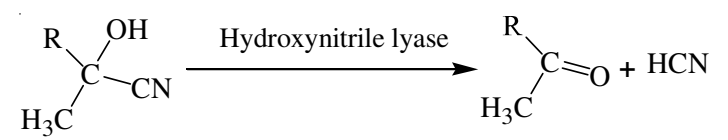

$\mathrm{R}=\mathrm{CH}_{3}$ in case of acetone cyanohydrin, $\mathrm{R}=\mathrm{C}_{6} \mathrm{H}_{5}$ in case of acetophenone cyanohydrin

Hydrolysis and dissociation of both acetone cyanohydrin and acetophenone cyanohydrin exhibited acute toxicity supporting ${ }^{8}$. Although chemically acetophenone cyanohydrin produces $\mathrm{HCN}$ easier that acetone cyanohydrin due to the phenyl ring that facilitates formation of carbonyl group and liberation of $\mathrm{HCN}$, acetone cyanohydrin appeared more effective than acetophenone cyanohydrin after two days exposure followed by non-significant differences after 4, 7 and 10 days exposure. This effect may be referred to 17.7 and $30.6 \%$ cyanide percent in acetophenone cyanohydrin and acetone cyanohydrin, respectively reflecting the excess of cyanide reaching the snail in acetone cyanohydrin at the same concentration compensating the resonance and causing the higher activity.

Lethal effects of the tested inorganic cyanides (metallocyanide derivatives (Tables 3 and 4) were also differed according to their structures, concentration and exposure time. Although cuprous thiocyanate (CuSCN) showed weak molluscicidal activity with mortality percent as high as $23.8 \%$ at the highest concentration (10\%) for 10 days, it appeared more effective than potassium ferrocyanide and potassium ferricyanide at all the tested concentrations. These three tested compounds 


\begin{tabular}{|c|c|c|c|c|c|c|c|c|c|c|c|}
\hline & & & $\begin{array}{l}\text { MORTAL } \\
\text { SHOWN }\end{array}$ & $\begin{array}{l}\text { ITY EFFECT } \\
\text { S AVERAGH }\end{array}$ & $\begin{array}{l}\text { TA } \\
\text { S OF THE T1 } \\
\text { MORTALI? }\end{array}$ & $\begin{array}{l}\text { BLE - } 3 \\
\text { ESTED CON } \\
\text { Y PERCEN }\end{array}$ & $\begin{array}{l}\text { MPOUNDS O } \\
\text { ITS } \pm \text { SD ANI }\end{array}$ & $\begin{array}{l}\text { Theba pisar } \\
\text { LC }_{50} \text { VALU }\end{array}$ & & & \\
\hline Compound & Davs & & & & Concentratior & s (\%) & & & $\mathrm{LC}_{50} 95 \%$ & Slone + SF & $\gamma^{2}$ \\
\hline Compound & Days & 0 & 0.1 & 0.5 & 1 & 2 & 5 & 10 & C L & Slope \pm SE & $\chi^{2}$ \\
\hline & 2 & 0.0 & 0.0 & 0.0 & 0.0 & 0.0 & 0.0 & 0.0 & $>10$ & - & - \\
\hline Acetonitrile & 4 & 0.0 & 0.0 & 0.0 & $3.3 \pm 5.77$ & $3.3 \pm 5.77$ & $6.7 \pm 5.77$ & $10.0 \pm 0.00$ & $>10$ & - & - \\
\hline Acetomintाए & 7 & 0.0 & 0.0 & 0.0 & $3.3 \pm 5.77$ & $6.7 \pm 5.77$ & $10.0 \pm 0.00$ & $13.3 \pm 5.77$ & $>10$ & - & - \\
\hline & 10 & 0.0 & 0.0 & 0.0 & $3.3 \pm 5.77$ & $10.0 \pm 0.00$ & $13.3 \pm 5.77$ & $23.3 \pm 5.77$ & $>10$ & - & - \\
\hline & 2 & 0.0 & 0.0 & $63.3 \pm 5.77$ & $93.3 \pm 5.77$ & 100 & 100 & 100 & $\begin{array}{c}0.43 \\
0.37-0.49\end{array}$ & $4.4 \pm 0.28$ & 1.0 \\
\hline Acetone & 4 & 0.0 & $3.3 \pm 5.77$ & $66.7 \pm 5.77$ & 100 & 100 & 100 & 100 & $\begin{array}{c}0.34 \\
0.3-0.39\end{array}$ & $3.9 \pm 0.13$ & 7.7 \\
\hline cyanohydrin & 7 & 0.0 & $16.7 \pm 5.77$ & $73.3 \pm 5.77$ & 100 & 100 & 100 & 100 & $\begin{array}{c}0.24 \\
0.2-0.29\end{array}$ & $2.84 \pm 0.05$ & 9.9 \\
\hline & 10 & 0.0 & $23.3 \pm 5.77$ & $86.7 \pm 5.77$ & 100 & 100 & 100 & 100 & $\begin{array}{c}0.18 \\
0.16-0.21 \\
\end{array}$ & $2.93 \pm 0.06$ & 2.9 \\
\hline & 2 & 0.0 & 0.0 & $33.3 \pm 11.55$ & $93.3 \pm 5.77$ & 100 & 100 & 100 & $\begin{array}{c}0.58 \\
0.54-0.63\end{array}$ & $6.4 \pm 0.56$ & 3.0 \\
\hline Acetophenone & 4 & 0.0 & $3.3 \pm 5.77$ & $46.7 \pm 11.55$ & $96.7 \pm 5.77$ & 100 & 100 & 100 & $\begin{array}{c}0.43 \\
0.37-0.49\end{array}$ & $0.31 \pm 0.13$ & 17.3 \\
\hline cyanohydrin & 7 & 0.0 & $13.3 \pm 5.77$ & $60.0 \pm 10.0$ & 100 & 100 & 100 & 100 & $\begin{array}{c}0.29 \\
0.25-0.34\end{array}$ & $\begin{array}{c}2.83 \pm \\
0.05\end{array}$ & 20.7 \\
\hline & 10 & 0.0 & $26.7 \pm 5.77$ & $73.3 \pm 15.27$ & 100 & 100 & 100 & 100 & $\begin{array}{c}0.20 \\
0.17-0.24\end{array}$ & $2.43 \pm 0.04$ & 13.3 \\
\hline & 2 & 0.0 & $3.3 \pm 5.77$ & $3.3 \pm 5.77$ & $3.3 \pm 5.77$ & $6.7 \pm 5.77$ & $6.7 \pm 5.77$ & $26.7 \pm 15.28$ & $>10$ & - & - \\
\hline & 4 & 0.0 & $3.3 \pm 5.77$ & $3.3 \pm 5.77$ & $6.7 \pm 5.77$ & $10.0 \pm 5.77$ & $13.3 \pm 5.77$ & $36.7 \pm 5.77$ & $>10$ & - & - \\
\hline $\begin{array}{l}\text { Ethylcyano- } \\
\text { acetic acid } \\
\text { ester }\end{array}$ & 7 & 0.0 & $3.3 \pm 5.77$ & $6.7 \pm 5.77$ & $10.0 \pm 0.00$ & $13.3 \pm 5.77$ & $26.7 \pm 5.77$ & $66.7 \pm 5.77$ & $\begin{array}{c}9.1 \\
6.7-13.2\end{array}$ & $1.25 \pm 0.02$ & 26.3 \\
\hline & 10 & 0.0 & $6.7 \pm 5.77$ & $10.0 \pm 0.00$ & $13.3 \pm 5.77$ & $26.7 \pm 5.77$ & $36.0 \pm 5.77$ & $73.3 \pm 15.27$ & $\begin{array}{c}6.1 \\
4.5-8.5 \\
\end{array}$ & $1.12 \pm 0.013$ & 22.7 \\
\hline & 2 & 0.0 & 0.0 & 0.0 & 0.0 & 0.0 & 0.0 & 0.0 & $>10$ & - & - \\
\hline $\begin{array}{l}\text { Cuprous } \\
\text { thicyanat }\end{array}$ & 4 & 0.0 & 0.0 & $4.8 \pm 8.26$ & $14.3 \pm 24.77$ & $9.5 \pm 8.26$ & $14.3 \pm 0.06$ & $19.1 \pm 8.26$ & $>10$ & - & - \\
\hline$(\mathrm{CuSCN})$ & 7 & 0.0 & $4.8 \pm 8.26$ & $4.8 \pm 8.26$ & $19.1 \pm 21.84$ & $14.3 \pm 14.3$ & $19.1 \pm 8.26$ & $23.8 \pm 8.26$ & $>10$ & - & - \\
\hline & 10 & 0.0 & $4.7 \pm 8.26$ & $4.7 \pm 8.26$ & $19.1 \pm 21.84$ & $19.1 \pm 8.27$ & $19.1 \pm 8.27$ & $23.8 \pm 8.26$ & $>10$ & - & - \\
\hline & 2 & 0.0 & $3.3 \pm 5.77$ & $3.3 \pm 5.77$ & $20.0 \pm 10.0$ & $43.3 \pm 5.77$ & $53.3 \pm 5.77$ & $56.7 \pm 5.77$ & $\begin{array}{c}5.1 \\
3.9-6.8\end{array}$ & $1.19 \pm 0.013$ & 16.4 \\
\hline Mercuric & 4 & 0.0 & $3.3 \pm 5.77$ & $26.7 \pm 15.28$ & $30.0 \pm 10.0$ & $76.7 \pm 5.77$ & $86.7 \pm 11.55$ & $96.7 \pm 5.77$ & $\begin{array}{c}1.38 \\
1.01-1.19\end{array}$ & $1.9 \pm 0.018$ & 14.5 \\
\hline $\begin{array}{c}\text { cyanide } \\
{\left[\mathrm{Hg}(\mathrm{CN})_{2}\right]}\end{array}$ & 7 & 0.0 & $\begin{array}{c}13.3 \pm \\
5.77\end{array}$ & $33.3 \pm 11.55$ & $53.3 \pm 5.77$ & $90.0 \pm 10.0$ & 100 & 100 & $\begin{array}{c}0.62 \\
0.52-0.72\end{array}$ & $1.97 \pm 0.02$ & 27.9 \\
\hline & 10 & 0.0 & $16.7 \pm 5.77$ & $73.3 \pm 15.28$ & $96.7 \pm 5.77$ & 100 & 100 & 100 & $\begin{array}{c}0.25 \\
0.21-0.29 \\
\end{array}$ & $2.7 \pm 0.05$ & 4.01 \\
\hline & 2 & 0.0 & $20.0 \pm 10.0$ & $47.7 \pm 16.51$ & $76.7 \pm 5.77$ & $96.7 \pm 5.77$ & 100 & 100 & $\begin{array}{c}0.37 \\
0.20-0.45\end{array}$ & $1.81 \pm 0.027$ & 11.8 \\
\hline Potassium & 4 & 0.0 & $33.4 \pm 21.84$ & $61.9 \pm 8.20$ & $86.7 \pm 11.55$ & 100 & 100 & 100 & $\begin{array}{c}0.22 \\
0.17-0.27\end{array}$ & $1.71 \pm 0.026$ & 13.1 \\
\hline $\begin{array}{l}\text { cyanıde } \\
(\mathrm{KCN})\end{array}$ & 7 & 0.0 & $38.1 \pm 21.84$ & $66.7 \pm 8.19$ & $96.7 \pm 5.77$ & 100 & 100 & 100 & $\begin{array}{c}0.17 \\
0.14-0.22\end{array}$ & $1.87 \pm 0.031$ & 18.5 \\
\hline & 10 & 0.0 & $42.9 \pm 14.3$ & $71.5 \pm 0.17$ & 100 & 100 & 100 & 100 & $\begin{array}{c}0.15 \\
0.11-0.18 \\
\end{array}$ & $1.91 \pm 0.034$ & 21.8 \\
\hline & 2 & 0.0 & 0.0 & 0.0 & 0.0 & 0.0 & $3.3 \pm 5.77$ & $6.7 \pm 5.77$ & $>10$ & - & - \\
\hline $\begin{array}{l}\text { Potassium } \\
\text { ferrocyanide }\end{array}$ & 4 & 0.0 & 0.0 & 0.0 & 0.0 & 0.0 & $66.7 \pm 5.77$ & $10.0 \pm 0.00$ & $>10$ & - & - \\
\hline $\begin{array}{l}\mathrm{K}_{4}\left[\mathrm{Fe}(\mathrm{CN})_{6}\right] \\
\end{array}$ & 7 & 0.0 & 0.0 & $3.3 \pm 5.77$ & $3.3 \pm 5.77$ & $6.7 \pm 5.77$ & $10.0 \pm 0.00$ & $13.3 \pm 5.77$ & $>10$ & - & - \\
\hline & 10 & 0.0 & $3.3 \pm 5.77$ & $6.7 \pm 5.77$ & $6.7 \pm 5.77$ & $10.0 \pm 0.00$ & $13.3 \pm 5.77$ & $16.7 \pm 5.77$ & $>10$ & - & - \\
\hline & 2 & 0.0 & 0.0 & 0.0 & 0.0 & $3.3 \pm 5.77$ & $6.7 \pm 5.77$ & $6.7 \pm 5.77$ & $>10$ & - & - \\
\hline $\begin{array}{l}\text { Potassium } \\
\text { ferricvanide }\end{array}$ & 4 & 0.0 & 0.0 & 0.0 & 0.0 & $6.7 \pm 5.77$ & $10.0 \pm 10.0$ & $13.3 \pm 5.77$ & $>10$ & - & - \\
\hline $\mathrm{K}_{3}\left[\mathrm{Fe}(\mathrm{CN})_{6}\right]$ & 7 & 0.0 & 0.0 & 0.0 & 0.0 & $10.0 \pm 0.0$ & $13.3 \pm 5.77$ & $16.7 \pm 5.77$ & $>10$ & - & - \\
\hline & 10 & 0.0 & 0.0 & 0.0 & 0.0 & $13.3 \pm 5.77$ & $16.7 \pm 5.77$ & $20.0 \pm 10.0$ & $>10$ & - & - \\
\hline & 2 & 0.0 & 0.0 & 0.0 & 0.0 & 0.0 & 0.0 & 0.0 & $>10$ & - & - \\
\hline Potassium & 4 & 0.0 & 0.0 & 0.0 & 0.0 & 0.0 & $13.3 \pm 11.55$ & $30.0 \pm 10.0$ & $>10$ & - & - \\
\hline thiocyanate & 7 & 0.0 & 0.0 & 0.0 & 0.0 & $6.7 \pm 5.77$ & $23.3 \pm 5.77$ & $46.7 \pm 5.77$ & $>10$ & - & - \\
\hline$(\mathrm{KSCN})$ & 10 & 0.0 & 0.0 & 0.0 & 0.0 & $13.3 \pm 5.77$ & $46.7 \pm 15.28$ & $56.7 \pm 5.77$ & $\begin{array}{c}6.9 \\
5.8-8.2\end{array}$ & $2.3 \pm 0.05$ & 10.2 \\
\hline
\end{tabular}




\begin{tabular}{|c|c|c|c|c|c|c|c|c|c|c|c|}
\hline \multirow{4}{*}{$\begin{array}{l}\text { Sodium } \\
\text { cyanide } \\
(\mathrm{NaCN})\end{array}$} & 2 & 0.0 & $13.3 \pm 5.77$ & $50.0 \pm 26.46$ & $93.3 \pm 5.77$ & 100 & 100 & 100 & $\begin{array}{c}0.35 \\
0.29-0.40\end{array}$ & $2.56 \pm 0.04$ & 20.4 \\
\hline & 4 & 0.0 & $20.0 \pm 0$ & $60.0 \pm 10$ & 100 & 100 & 100 & 100 & $\begin{array}{c}0.26 \\
0.22-0.31\end{array}$ & $2.50 \pm 0.041$ & 25.4 \\
\hline & 7 & 0.0 & $23.3 \pm 5.77$ & $63.3 \pm 15.28$ & 100 & 100 & 100 & 100 & $\begin{array}{c}0.24 \\
0.2-0.28\end{array}$ & $2.40 \pm 0.039$ & 23.2 \\
\hline & 10 & 0.0 & $30.0 \pm 10.0$ & $66.7 \pm 11.55$ & 100 & 100 & 100 & 100 & $\begin{array}{c}0.2 \\
0.17-0.24\end{array}$ & $2.20 \pm 0.036$ & 22.3 \\
\hline
\end{tabular}

\begin{tabular}{|c|c|c|c|c|c|c|}
\hline \multicolumn{7}{|c|}{$\begin{array}{l}\text { TABLE-4 } \\
\text { LETHALITY OF THE TESTED COMPOUNDS ON Theba pisana, SHOWN AS LT }{ }_{50} \text { VALUES }^{\text {VA }}\end{array}$} \\
\hline \multirow{2}{*}{ Compound } & & \multicolumn{5}{|c|}{$\mathrm{LT}_{50}$ values at different concentrations \% (days) } \\
\hline & & 0.5 & 1 & 2 & 5 & 10 \\
\hline Acetonitrile & $\mathrm{LT}_{50}$ & $>10$ & $>10$ & $>10$ & $>10$ & $>10$ \\
\hline Acetone cyanohydrin & $\mathrm{LT}_{50}$ & $<2$ & $<2$ & $<2$ & $<2$ & $<2$ \\
\hline \multirow[t]{3}{*}{ Acetophenone cyanohydrin } & $\mathrm{LT}_{50}$ & $4.2(3.4-5.2)$ & $<2$ & $<2$ & $<2$ & $<2$ \\
\hline & Slope \pm SE & $1.5 \pm 0.06$ & - & - & - & - \\
\hline & $\chi^{2}$ & 0.85 & - & - & - & - \\
\hline \multirow[t]{3}{*}{ Ethylcyano- acetic acid ester } & $\mathrm{LT}_{50}$ & $>10$ & $>10$ & $>10$ & $>10$ & $4.8(4.1-5.6)$ \\
\hline & Slope \pm SE & - & - & - & - & $1.9 \pm 0.07$ \\
\hline & $\chi^{2}$ & - & - & - & - & 3.6 \\
\hline Cuprous thiocyanate & $\mathrm{LT}_{50}$ & $>10$ & $>10$ & $>10$ & $>10$ & $>10$ \\
\hline \multirow[t]{4}{*}{ Mercuric cyanide } & $\mathrm{LT}_{50}$ & $7.4(6.3-8.3)$ & $5.2(4.6-5.9)$ & $2.3(2.0-2.7)$ & $<2$ & $<2$ \\
\hline & Slope \pm SE & $3.1 \pm 0.1$ & $2.6 \pm 0.1$ & $3.1 \pm 0.1$ & - & - \\
\hline & $\chi^{2}$ & 12.4 & 15.3 & 4.3 & - & - \\
\hline & $\tilde{\mathrm{LT}}_{50}$ & $2.1(1.2-3.6)$ & $<2$ & $<2$ & $<2$ & $<2$ \\
\hline \multirow[t]{2}{*}{ Potassium cyanide } & Slope \pm SE & $0.9 \pm 0.6$ & - & - & - & - \\
\hline & $\chi^{2}$ & 0.36 & - & - & - & - \\
\hline Potassium ferrocyanide & $\mathrm{LT}_{50}$ & $>10$ & $>10$ & $>10$ & $>10$ & $>10$ \\
\hline Potassium ferricyanide & $\mathrm{LT}_{50}$ & $>10$ & $>10$ & $>10$ & $>10$ & $>10$ \\
\hline \multirow[t]{3}{*}{ Potassium thiocyanate } & $\mathrm{LT}_{50}$ & $>10$ & $>10$ & $>10$ & $>10$ & $7.75(6.8-8.8)$ \\
\hline & Slope \pm SE & - & - & - & - & $2.9 \pm 0.1$ \\
\hline & $\chi^{2}$ & - & - & - & - & 11.9 \\
\hline Sodium cyanide & $\tilde{\mathrm{LT}}_{50}$ & $<2$ & $<2$ & $<2$ & $<2$ & $<2$ \\
\hline
\end{tabular}

showed $\mathrm{LC}_{50}$ values more than $10 \%$ with $\mathrm{LT}_{50}$ values more than 10 days (Table-4).

Potassium thiocyanate showed low toxicity with $6.7 \%$ mortality started after 2 days exposure exhibiting $>10 \% \mathrm{LC}_{50}$ value and $>10$ days $\mathrm{LT}_{50}$ value till $5 \%$ concentration. Its effect was increased at 10-6.9\% $\mathrm{LC}_{50}$ value after 10 days exposure and 7.8 days $\mathrm{LT}_{50}$ value.

Mercuric cyanide exceeded the previous explained inorganic derivatives. Its lethal effect was increased with increasing either the tested concentration or the exposure time at the same concentration causing $5.1,1.38,0.62$ and $0.25 \% \mathrm{LC}_{50}$ values after 2, 4, 7 and 10 days exposure time, respectively (Table-3) with $\mathrm{LT}_{50}$ values $7.4,5.2,2.3,<2$ and $<2$ days at $0.5,1.0,2.0$, 5.0 and $10 \%$ concentration, respectively (Table-4).

Both potassium cyanide and sodium cyanide were the most active compounds with non significance between each other. Their lethal effects against the treated snail started at the lowest concentration $(0.1 \%)$ increased with increasing either concentration or exposure time reaching $100 \%$ mortality of the treated snail population. They exhibited $0.37,0.22,0.17$ and $0.15 \%$ in comparison to $0.35,0.26,0.24$ and $0.2 \% \mathrm{LC}_{50}$ values after 2, 4, 7 and 10 days exposure in treatment with potassium cyanide and sodium cyanide, respectively (Table-3). Their $\mathrm{LT}_{50}$ values were $<2.0$ days at all concentrations.
From the mentioned results, presence of sulfur atom in the derivative structure (thiocyanate derivatives) reduced the toxicity against the used snail. These data go with Pope and Rall $^{15}$ as they described that even inside the animal, the enzymes catalyze a sulfur atom transfer to combine with the cyanide forming the less toxic thiocyanate structure, which is excreted. So the used thiocyanate derivatives were slower than others in reaching the site of action in addition to their low acute toxicity. Thiocyanate $\left(\mathrm{SCN}^{-}\right)$is also a weak-acid dissociables (WAD) and its toxicity is a concern at elevated concentrations ${ }^{16}$.

Much lower toxicities of the ferrocyanide and ferricyanide complexions are due to high stability under normal temperatures and pressures ${ }^{17}$ and so they are not likely to be of practical importance. However cyanide radicals have a low affinity for alkali metals and a high affinity for ferric ion $\left(\mathrm{Fe}^{3+}\right)$ and other metals. Therefore, simple cyanide salts (for example, sodium cyanide or potassium cyanide) are toxic, whereas certain iron-containing cyanide compounds do not release $\mathrm{CN}^{-}$readily and are nearly nontoxic emphasizing our biological results.

So it could be deduced that as well known, the effect of cyanogenic glycosides and other cyanide derivatives is referred to hydrolysis liberating cyanide expressed as hydrocyanic acid, derived from ionization, dissociation and photodecomposition 
of cyanide-containing compounds which has acute toxicity and other corresponding carbonyl components ${ }^{8}$. The effect of cyanide might be due to coordination with the active site of peroxidases at which $\mathrm{H}_{2} \mathrm{O}_{2}$ reduction is catalyzed ${ }^{18}$.

Cyanide inactivates several enzymes (particularly those containing iron in the ferric $\left(\mathrm{Fe}^{3+}\right)$ state and cobalt) and nonenzymatic proteins. It exerts its ultimate lethal effect by binding cytochrome $c$ oxidase in minutes preventing the transfer of electrons to molecular oxygen causing intracellular hypoxia. Thus, it cannot be utilized toward (ATP) generation stopping aerobic cell metabolism and affecting the nervous system and the heart ${ }^{19-21}$. Cyanide also inhibits antioxidant enzymes such as catalase, superoxide dismutase, cytochrome oxidase and glutathione peroxidase as well as carbonic anhydrase.

Environmentally, the general population is exposed to cyanides primarily by ingestion of food and water and to a lesser degree, by inhalation. The half-life for the conversion of cyanide to thiocyanate [major pathway $(80 \%)$ for cyanide metabolism] in the presence of a sulfur donor (e.g., thiosulfate) in humans is between 20 and $60 \mathrm{~min}^{22}$. This reaction is catalyzed by rhodanese and subsequently excreted in the urine ${ }^{23-25}$. Other significant metabolic pathway is the conversion of cyanide to 2-amino-2-thiazoline-4-carboxylic acid (ATCA) by its reaction with cystine ( $c a .20 \%$ of its metabolism) besides other minor pathways including the creation of one-carbon metabolites and protein adducts. This percentage increases with toxic doses of cyanide $^{26-27}$.

Human exposure to small amounts of cyanide will have no effect. Cyanide is a non-carcinogenic priority pollutant as no epidemiological studies or case reports investigating the association of exposure to potassium ferricyanide and cancer risk in humans were identified in the available literature ${ }^{17}$. Most authorities now agree that cyanide has low persistence in the environment and is not accumulated or stored in any mammal studied and its biomagnification in food has not been reported, possibly due to rapid detoxification of sub lethal doses. Sodium cyanide is readily biodegradable and no bioaccumulation is expected. No evidence that the material is carcinogenic based on available data ${ }^{28}$. Cyanide can be removed by several processes within cells. Perhaps of greatest importance is the formation of cyanomethemoglobin in red blood cells. Rhodanese, mercaptopyruvate sulfur transferase, thiosulfate reductase and cystathionase intracellular enzymes may be involved in cyanide detoxification. Acetone cyanohydrin decomposes into cyanide and acetone spontaneously above $\mathrm{pH} 4$ and temperatures above $30^{\circ} \mathrm{C}^{29,30}$. So, it could be concluded that because of the environmental safety of using the cyanide derivatives, this research pointed to an alternative chemical group controlling snails.

\section{ACKNOWLEDGEMENTS}

The authors extend their appreciation to the Deanship of Scientific Research at King Saud University for funding this work through research group "RGP-VPP-010".

\section{REFERENCES}

1. M.M. El-Okda, J. Agric. Res. Rev., 58, 79 (1980).

2. E. Miller, S. Swails, D. Swails, F. Olsan and R.T. Staten, J. Agric. Entomol., 5, 189 (1988).

3. H.E. Lokma and F.N. Al-herby, Zagazig J. Agric. Res., 26, 437 (1997).

4. M.A. Okka, J. Agric. Sci. Mansoura Univ., 22, 4637 (1997).

5. M. Miyazawa, H. Utsunomiya, K. Inada, T. Yamada, Y. Okuno, H. Tanaka and M. Tatematsu, Biol. Pharm. Bull., 29, 172 (2006).

6. S. Bak, S.M. Paquette, M. Morant, A.V. Morant, S. Saito, N. Bjarnholt, M. Zagrobelny, K. Jørgensen, S. Osmani, H.T. Simonsen, R.S. Pérez, T.B. Heeswijck, B. Jørgensen and B.L. Møller, Phytochem. Rev., 5, 309 (2006)

7. L.G. Stowe and B.S. Kil, in eds.: R.F. Keeler and A.T. Tu, Handbook of Natural Toxins, Marcel Dekker, New York, vol. 1, pp. 707-741 (1983).

8. R. Bhunya, T. Mahapatra and S. Nanda, Tetrahedron Asymm., 20, 1526 (2009).

9. A.S. Abdel-Aty, J. Pest Control Environ. Sci., 18, 135 (2010).

10. E.A. Malek and T.C. Cheng, Medical and Economic Malacology, Academic Press Inc. (London Ltd.), pp. 285 -319 (1974).

11. A.I. Vogel, edn 4, pp. 881-884, Thames Polytechnic London (1976).

12. A.S. Abdel-Aty, World J. Agric. Sci., 5, 105 (2009).

13. D.J. Finney, Probit Analysis, Cambridge University Press, London, edn 3, p. 138 (1971).

14. J.E. Poulton, Ciba Found. Symp., 140, 67 (1988).

15. A.M. Pope and D.P. Rall, Environmental Medicine: Integrating a Missing Element into Medical Education, National Academy Press, Washington, DC, pp. 317-323 (1995).

16. C. Boucabeille, A. Bories, P. Ollivier and G. Michel, Environ. Pollut., 84, 59 (1994).

17. R.J. Lewis, Hawley's Condensed Chemical Dictionary, Van Nostrand Reinhold, Co., New York, edn 12, pp. 952 (1993).

18. T. Tatsuma, K. Tani, T. Ogawa and N. Oyama, Sens. Actuators B, 49, 268 (1998).

19. K. Alexander and S.I. Baskin, Biochim. Biophys. Acta, 912, 41 (1987).

20. M. Lindahl, L.A. Svensson and A. Liljas, Proteins, 15, 177 (2004).

21. B.L. Møller, Curr. Opin. Plant Biol., 13, 337 (2010).

22. CHEM-BANK, Health \& Safety Publishing, Norwood, MA (CDROM) (1999).

23. S.I. Baskin, I. Petrikovics, J.S. Kurche, J.D. Nicholson, B.A. Logue, B.J. Maliner and G.A. Rockwood, in eds.: S.J.S. Flora, J.A. Romano Jr., S.I. Baskin and K. Sekhar, Insights on Cyanide Toxicity and Methods of Treatment. In: Pharmacological Perspectives of Toxic Chemicals and Their Antidotes, Narosa Publishing House, New Delhi, Chap. 9, pp. 105-146 (2004).

24. A. Salkowski and D. Penney, Vet. Hum. Toxicol., 36, 455 (1994).

25. A.B. Sousa, H. Manzano, B. Soto-Blanco and S.L. G'orniak, Arch. Toxicol., 77, 330 (2004).

26. S.I. Baskin and T.G. Brewer in eds.: F.R. Sidell, E.T. Takafuji and D.R. Franz, Medical Aspects of Chemical and Biological Warfare, Ch. 10, pp. 271-286 (1997).

27. M.J. Fasco, C.R. Hauer, R.F. Stack, C. O'Hehir, J.R. Barr and G.A. Eadon, Chem. Res. Toxicol., 20, 677 (2007).

28. Scientific Committee on Occupational Exposure Limits SCOEL/SUM/ 115. Report no: 115. (2005).

29. J.A. Montagnac, C.R. Davis and S.A. Tanumihardjo, In Comprehensive Reviews in Food Science and Food Safety, 8, 17 - 27 (2008).

30. J.L. Borowitz, G.E. Isom and S.I. Bask, in eds.: S.M. Somani and J.A. Romano, Jr., Acute and Chronic Cyanide Toxicity, in Chemical Warfare Agents: Toxicity at Low Levels (CRC Press, Boca Raton, pp. 301-319 (2001). 